\title{
TOTAL PHENOLIC CONTENTS, ANTIOXIDANT, ANTICANCER AND ANTIDIABETIC PROPERTIES OF Myrmecodia tuberosa (RUBIACEAE)
}

\author{
Saidi Rasemi ${ }^{1}$, Khong Heng Yen ${ }^{1^{\star}}$ Rohaya Ahmad $^{2}$ and Mizaton Hazizul Hasan ${ }^{3}$ \\ ${ }^{1 *}$ Faculty of Applied Sciences, Universiti Teknologi MARA, 94300 Kota Samarahan, Sarawak, Malaysia \\ *khonghy@sarawak.uitm.edu.my \\ ${ }^{2}$ Faculty of Applied Sciences, Universiti Teknologi MARA, 40450 Shah Alam, Malaysia \\ rohayaahmad@salam.uitm.edu.my \\ ${ }^{3}$ Faculty of Pharmacy, Universiti Teknologi MARA, 40450 Shah Alam, Malaysia \\ Mizaton_hazizul@salam.uitm.edu.my
}

\begin{abstract}
Myrmecodia tuberosa, locally known as "Sarang Semut", belongs to the Rubiaceae family. The aim of the study is to investigate the total phenolic contents and bioactivity of the crude extract of $M$. tuberosa. The tuber, bark and leaves of the plant were cut, washed and air-dried. The plant was extracted with ethyl acetate and ethanol to yield EtOAc and EtOH crudes. The crudes were then tested for antioxidant 2,2-diphenyl-1-(2,4,6-trinitrophenyl)hydrazyl (DPPH) assay, $\alpha$-glucosidase assay for anti-diabetic activity and [3-(4,5-Dimethylthiazol-2-yl)-2,5-diphenyl tetrazolium] MTT Assay for cytotoxicity test. The results showed that bark ethanolic extract demonstrated the highest DPPH scavenging of $95.16 \%$ while other crudes were ranging from $92.77 \%$ to $94.55 \%$ scavenging of DPPH compared to ascorbic acid. The tuber ethyl acetate extract demonstrated the highest inhibition of $\alpha$-glucosidase enzyme with $72.58 \%$ while other crudes were ranging from $63.27 \%$ to $72.46 \%$ inhibition. In addition, the ethanolic tuber extract exhibited the strongest cytotoxicity against Human colorectal Cancer (HT-29) and Cervical Cancer (HeLa) cell lines with the $\mathrm{IC}_{50}$ value of $16 \mu \mathrm{g} / \mathrm{mL}$ and $14 \mu \mathrm{g} / \mathrm{mL}$ respectively. Meanwhile, the ethanolic bark extract exhibited the strongest cytotoxicity against Human Breast Cancer (MCF-7) with $\mathrm{IC}_{50}$ value of $6.0 \mu \mathrm{g} / \mathrm{mL}$. Furthurmore, the tuber extracts contained the highest phenolic content with $1087 \mathrm{mg} \mathrm{GAE} / \mathrm{g}$ extract compared to the leaves and barks of the plants. The findings suggest that the whole part of $M$. tuberosa is a potential natural source for anti-oxidative, anti-diabetic and anti-cancer agent.
\end{abstract}

\section{Indexing terms/Keywords}

Rubiaceae; Myrmecodia tuberosa; Antioxidant, Anticancer; Antidiabetic.

\section{Academic Discipline And Sub-Disciplines}

Chemistry; Natural Products

\section{SUBJECT CLASSIFICATION}

Natural Drugs Discovery

\section{TYPE (METHOD/APPROACH)}

\section{Experimental}

\section{Council for Innovative Research}

\author{
Peer Review Research Publishing System
}

\section{Journal: Journal of Advances in Chemistry}

Vol. 9, No. 3

editorjaconline@gmail.com

www.cirworld.org/journals 


\section{INTRODUCTION}

Myrmecodia tuberosa locally known as "Sarang Semut", belongs to Rubiaceae family. Myrmecodia, together with Anthorrhiza, Hydnophytum, Myrmephytum and Squamellaria are the five known genera belong to the family of Rubiaceae that has tuber and epiphytic myrmecophytes. Myrmecodia genus has the second-widest distribution in the world ${ }^{[1]}$ after Hydnophytum genus. Myrmecodia sp. can be found in Malaysia, Philippines, south to the Cape York Peninsula in Queensland, southern Thailand, Cambodia, Vietnam and New Guinea ${ }^{[2]}$. Usually, the genera of Hydnophytum and Myrmecodia species are associated with Iridomyrmex ant species. However, other ant species of the genera like Anaplolepis, Camponotus, Crematogaster, Pedomyrma, Pheidole, Polyrachis, Monomorium, Technomyrex, Turneria, and Vollenhovia also reported live in the tuber of this plants ${ }^{[3]}$. The ant-plants are saturated by ant colonies, and they are aggressive towards enemies of the host plant and are important for plant defense ${ }^{[4]}$. Plant parts produce sweet secretions consumed by the ants, ${ }^{[5]}$ and the plant utilizes directly nutrients derived from animals ${ }^{[6]}$.

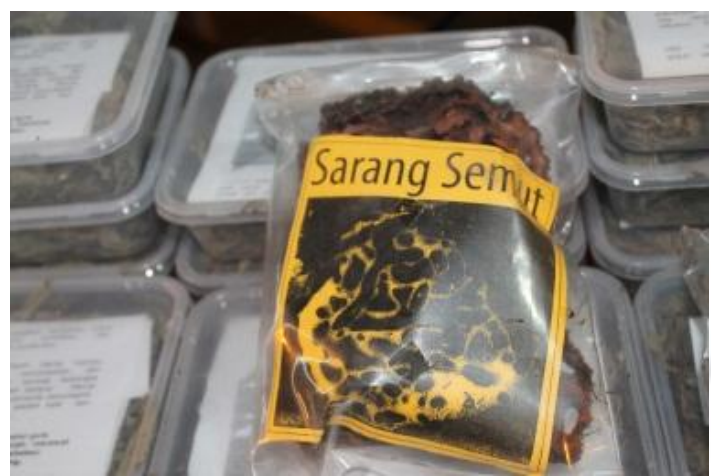

Pack of M.tuberosa selling at night market, Sabah

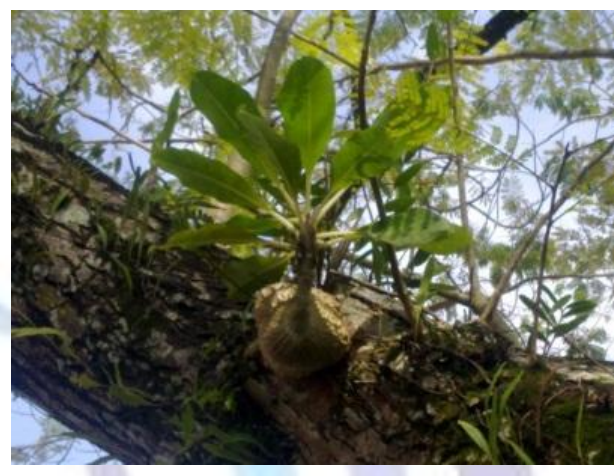

Natural habitat of Myrmecodia tuberosa

The plant is traditionally used in Malaysia and Indonesia as an alternative treatment for cancer and tumor especially, in breast, liver, lung, ovarian and brain cancer. This plant is also used to lowering the glucose level in the blood. Therefore, the aim of this study was to investigate the total phenolic contents and the potential of $M$. tuberosa as an antioxidant, anticancer and antidiabetic agent.

\section{METHODOLOGY}

\section{a) Preparation of EtOAc and EtOH crude}

The purchased plants sample from the local market were cleaned and cut into different parts; the tuber, bark and leaves of the plant. They were air-dried for three weeks before the plants were extracted with ethyl acetate $(3 \times 4$ days $)$ and ethanol (3 $\mathrm{X} 4$ days) to yield EtOAc and EtOH crude.

\section{b) Total Phenolic Content}

The modifications of Folin Ciocalteu assay by Kahkonen et al (1999) ${ }^{[7]}$ were used to determine the total phenolic compounds (TPC) of plant crude extract. A $1.5 \mathrm{~mL}$ of Folin-Ciocalteu reagent was diluted ten times and $1.2 \mathrm{~mL}$ of sodium carbonate $(7.5 \% \mathrm{w} / \mathrm{v})$ was added to $300 \mu \mathrm{L}$ of crude extracts in three replicate. The tubes were vortexed and stood for 30 minutes at $40^{\circ} \mathrm{C}$ for colour development. UV-VS spectrophotometer was used to monitor the absorbance of sample at 765 $\mathrm{nm}$. Total phenolic content were expressed as $\mathrm{mg}$ Gallic acid equivalents/g dry weight (GAE).

\section{c) DPPH Scavenging Activity}

Antioxidant reducing activity on DPPH radical is estimated according to the method of Blois (1958) ${ }^{[8]}$ with slightly modifications. The plant stock solution $(1 \mathrm{mg} / \mathrm{mL})$ was prepared by adding $1.0 \mathrm{mg}$ crude plant extract into $1.0 \mathrm{~mL}$ ethanol. The DPPH stock solution ( $1 \mathrm{mM}, 0.4 \mathrm{mg} / \mathrm{mL}$ ) prepared by using $2.0 \mathrm{mg}$ of DPPH in $5.0 \mathrm{~mL}$ of ethanol and used as negative control. The positive control was prepared by dissolving Ascorbic acid (A.A) $1.0 \mathrm{mg}$ with $1.0 \mathrm{~mL}$ ethanol to make solution concentration of $1 \mathrm{mg} / \mathrm{mL}$.

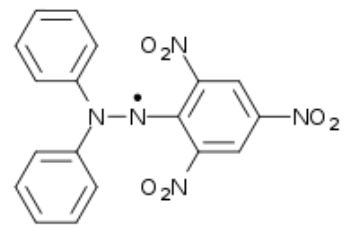

$$
\begin{aligned}
& \left(\mathrm{DPPH}^{*}\right)+(\mathrm{H}-\mathrm{A}) \rightarrow \underset{\text { Purple }}{\text { Dellow }} \\
& \text { PePH }-\mathrm{H}+\left(\mathrm{A}^{*}\right)
\end{aligned}
$$




\section{d) MTT assay}

Cell seeding for MTT assay was prepared to get 10,000 cells/well for each of HELA, HT-29 and MCF-7 cells and incubated overnight. The stock solution of samples with concentration $10 \mathrm{mg} / \mathrm{mL}$ was prepared as a cell treatment for MTT assay. Sample serial dilutions was performed starting with highest concentration and working down the well plate to get $30,15,7.5,3.75,1.875,0.375$ and $0.46875 \mu \mathrm{g} / \mathrm{mL}$ in each rows. The samples incubated for 24,48 and 72 hours for the samples to take effect. The optical density was monitored using UV Spectrophotometer at $570 \mathrm{~nm}$ and $630 \mathrm{~nm}$.

\section{e) Antidiabetic activities test ( $\alpha$-glucosidase inhibitors assay)}

Each well of 96 microliter plate was filled with $140 \mu \mathrm{L}$ phosphate buffers $(50 \mathrm{mM})$. In control wells, $15 \mu \mathrm{L}$ dimethysulphade (DMSO) was added. $15 \mu \mathrm{L}$ sample solution $(1 \mathrm{mg} / \mathrm{mL})$ was added in triplicate to the well. The enzyme solution $(20 \mu \mathrm{L})$ previously prepared by dissolving $0.2 \mathrm{mg}$ enzyme in $27.5 \mathrm{~mL}$ phosphate buffer was added to each well. The plate was incubated for 15 minutes at $37^{\circ} \mathrm{C}$. $25 \mu \mathrm{L}$ of substrate solution $(7 \mathrm{mM})$ of $p$-nitrophenyl- $\alpha$ - $D$-glucopyranosidase is quickly added to each well. The absorbance of the reaction mixture was taken within 30 minutes at $400 \mathrm{~nm}$

The calculation of inhibition percentage is as below:

$$
\% \text { inhibition }=\frac{(\text { Absorbance of control }- \text { absorbance of sample })}{\text { Absorbance of control }} \times 100 \%
$$

\section{RESULTS AND DISCUSSION}

\section{a) Total Phenolic Contents}

The results showed that the tuber extracts contained the highest phenolic content with $1087 \pm 0.06 \mathrm{mgGAE} / \mathrm{g}$ extract compared to the leaves and barks of the plants which only contain $669 \pm \mathrm{mgGAE} / \mathrm{g}$ and $523 \mathrm{mg} \pm 0.02 \mathrm{GAE} / \mathrm{g}$ extract respectively.

Table 1: Total phenolic contents in M.tuberosa

\begin{tabular}{|c|c|}
\hline Sample Extracts & $\begin{array}{c}\text { Total Phenolic Content } \\
(\mathrm{mg} \mathrm{GAE} / \mathrm{g} \text { extract })\end{array}$ \\
\hline MTB-E & $523 \pm 0.02$ \\
\hline MTL-E & $669 \pm 0.04$ \\
\hline MTT-E & $1087 \pm 0.06$ \\
\hline
\end{tabular}

Note: MTB-E: Ethanol Bark; MTL-E: Ethanol Leaves; MTT-E: Ethanol Tuber

\section{b) DPPH Scavenging Activity}

The results showed that the ethanolic bark extract demonstrated the highest DPPH scavenging of $95.16 \%$ while other part of extracts were ranging from $92.77 \%$ to $94.55 \%$ scavenging of DPPH compared to ascorbic acid (97.61\%). The highest percentage scavenging activity of Myrmecodia tuberosa against free radical DPPH shows that this plant contains very high antioxidant properties.

Table 2: DPPH scavenging activity

\begin{tabular}{|c|c|c|c|c|}
\hline Sample & $\pi$ & Concentration & $\begin{array}{c}\text { Mean } \\
\text { Absorbtion }\end{array}$ & $\begin{array}{c}\text { Scavenging of } \\
\text { DPPH (\%) }\end{array}$ \\
\hline Negative control & \multirow{7}{*}{$520 \mathrm{~nm}$} & \multirow{7}{*}{$1000 \mu \mathrm{g} / \mathrm{mL}$} & 1.4184 & - \\
\hline Positive control & & & 0.0338 & 97.6170 \\
\hline MTT-E & & & 0.0933 & 93.4222 \\
\hline MTT-EA-RT & & & 0.0807 & 94.3105 \\
\hline MTB-E & & & 0.0686 & 95.1636 \\
\hline MTL-E & & & 0.0773 & 94.5502 \\
\hline MTL-EA & & & 0.1025 & 92.7735 \\
\hline
\end{tabular}

Note: MTT-E: Ethanol Tuber; MTT-EA-RT: Ethyl acitate Tuber (remove tannins); MTB-E: Ethanol Bark; MTL-E: Ethanol Leaves; MTL-EA: Ethyl acetate Leaves. 


\section{c) MTT Assays}

The ethanolic tuber extract exhibited the strongest cytotoxicity against HT-29 and Hela cell lines with the $\mathrm{IC}_{50}$ value of 16 $\mu \mathrm{g} / \mathrm{mL}$ and $14 \mu \mathrm{g} / \mathrm{mL}$ respectively. Meanwhile, the ethanolic bark extract exhibited the strongest cytotoxicity against MCF-7 with $\mathrm{IC}_{50}$ value of $6.0 \mu \mathrm{g} / \mathrm{mL}$ as shown in the graph.

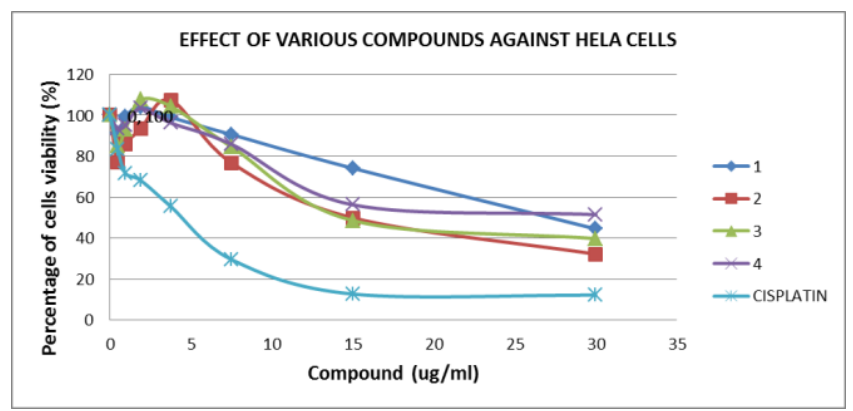

Figure 1: Effect of various extracts against HELA cells

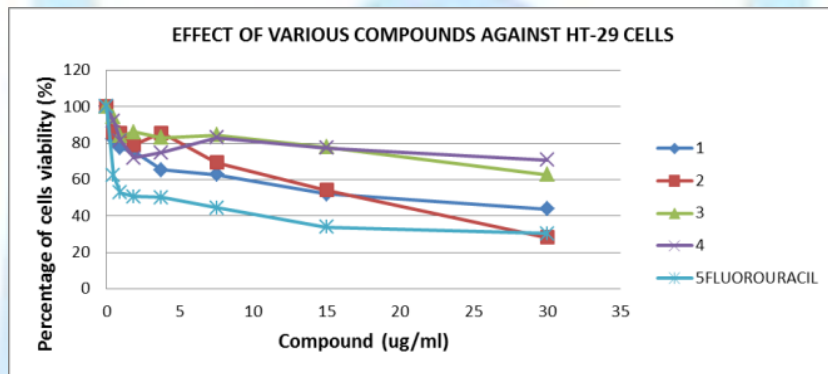

Figure 2: Effect of various extracts against HT-29 cells

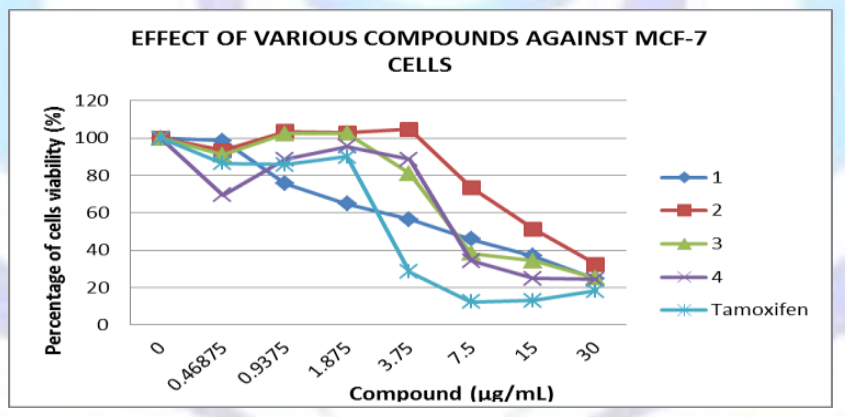

Figure 3: Effect of various extracts against MCF-7 cells

Note for Figure 1, Figure 2 and Figure 3: 1: Ethyl Acetate Tuber; 2: Ethanol Tuber; 3:Ethanol Leaves; 4: Ethanol Bark

\section{d) $\alpha$-Glucosidase InhibitoryActivity}

An in-Vitro $\alpha$-glucosidase assay (Anti-diabetic assay) of Myrmecodia tuberosa shows an average of $69.30 \%$ inhibitions of $\alpha$-glucosidase enzyme as shown in table 3.

The ethyl acetate extract of tuber $M$. tuberosa demonstrated the highest (72.58\%) inhibitions of $\alpha$-glucosidase enzyme while the others ranging from $72.46 \%$ to $63.27 \%$. This plant was considered has moderate activity of lowering the sugar level in blood for diabetic patients. 
Table 3: Percentage inhibitions of $\alpha$-glucosidase enzyme

\begin{tabular}{|c|c|c|c|c|}
\hline Sample & $\pi$ & Concentration & $\begin{array}{c}\text { Mean } \\
\text { Absorbtion }\end{array}$ & $\begin{array}{c}\text { Scavenging of } \\
\text { DPPH (\%) }\end{array}$ \\
\hline Control & \multirow{7}{*}{$400 \mathrm{~nm}$} & \multirow{7}{*}{$1000 \mu \mathrm{g} / \mathrm{mL}$} & 0.395 & - \\
\hline MTT-EA & & & 0.1451 & 72.5823 \\
\hline MTT-E & & & 0.1083 & 63.2658 \\
\hline MTB-E & & & 0.1088 & 72.4557 \\
\hline MTB-EA & & & 0.1250 & 68.3544 \\
\hline MTL-E & & & 0.1185 & 70.1266 \\
\hline MTL-EA & & & 0.1225 & 68.9873 \\
\hline
\end{tabular}

Note: MTT-EA: Ethyl acetate Tuber; MTT-E: Ethanol Tuber; MTB-E: Ethanol Bark; MTB-EA: Ethyl Acetate Bark; MTL-E: Ethanol Leaves; MTL-EA: Ethyl acetate Leaves;

\section{CONCLUSION}

The findings indicated that M.tuberosa is rich with phenolic contents. It also contains high antioxidant activity, strong cytotoxicity against MCF-7, HT-29 and HELA cell lines, and moderate antidiabetic activity.

\section{ACKNOWLEDGEMENT}

The authors wish to thank the RMI, Universiti Teknologi MARA for the Excellent Research Grant [600-RMU/DANA 5/3/ (9/2012)]; Mr. Hamsar, M. N. for his excellence technical assistance.

\section{REFERENCES}

[1] Huxley \& Jebb, M.H.P. 1991. The tuberous epiphytes of the Rubiaceae 1: A new subtribe - the Hydnophytinae. Blumea 36:1-20.

[2] Thompson JN (1981) Reversed animal-plant interactions:the evolution of insectivorous and ant-fed plants. Bot J Linn Soc 16:147-155

[3] Huxley, C.R. 1978. The ant-plants Myrmecodia and Hydnophytum (Rubiaceae), and the relationships between their morphology, ant occupants, physiology and ecology. New Phytologist 80: 231-268.

[4] Wilson EO. The nature of the taxon cycle in the Melanesian ant fauna. American Naturalist. 1961;95:169-193.

[5] Plummer, N., (2000). Cultivation of the epiphytic ant-plants Hydnophytum and Myrmecodia, Cactus and Succulent Journal $72: 142-147$

[6] M.P. Kahkonen, A.I. Hopia, H.J. Vuorela, J.P. Rauha, K. Pihlaja, T.S. Kujala et al. Antioxidant activity of plant extracts containing phenolic compounds Journal of Agricultural and Food Chemistry, 57 (1999), pp. 792-797.

[7] Pacini E, Nepi M. Nectar production and presentation. In: Nicolson SW, Nepi M, Pacini E, editors. Nectaries and nectar. Dordrecht: Springer; 2007. pp. 167-214

[8] Blois, M.S. 1958. Antioxidant determinations by the use of a stable free radical, Nature, 181: 1199-1200. 